\title{
AQUATIC AND MARSHY VEGETATION IN THE CENTER OF THE LOWER PLAIN OF SOMEȘ RIVER: GENERAL CHARACTERISATION
}

\author{
Manuela Octavia FECSKE \\ RO-400015, Cluj-Napoca, Romania \\ e-mail: manuelafecske@yahoo.com
}

Babeş-Bolyai University, Doctoral School of Integrative Biology, Republicii str. 42,

\begin{abstract}
Aiming to a larger study of vegetation of the lower Someș Plain (Romania), this short paper summarises the outcome of the floristic inventories performed in aquatic and marshy vegetation, which was dominant in the area until about three centuries ago when the extended wetland drainage has started. By using the phytosociological method, 20 plant associations assigned to four vegetation classes were distinguished. Without presenting phytosociological tables at this first stage, the syntaxonomical framework, distribution and species composition of the revealed plant communities are briefly discussed by reference to the process of wetland drying and successional change as well as to newly formed anthropogenic lakes. The conservative value of some plant community types is emphasized by mentioning the presence of several endangered species that are included in the European-level Habitats Directive and various regional or national red lists/books.
\end{abstract}

Keywords: drainage works, dry facies, endangered species, fragmented patches, insularization, remnant natural vegetation, ruderalization, species composition, syntaxonomical framework

\section{Introduction}

Located at the eastern end of the Pannonian Plain, the subdivision of the Someş River Plain (Samicum) has been strongly affected by human activities during the last three centuries, especially by land drainage of large areas previously occupied by swamps and ponds, coupled with embankments, stream channelisation, sod-turning, ground leveling and others [18].

The study area lies over three geographical subunits (Fig. 1): Ecedea Plain, Homorod Plain and Satu Mare-Micula Plain, as defined by Posea [28], along with four other subdivisions, all representing the lowest terrace of the Someș Plain.

The geological substratum consists largely of alluvial deposits, Pleistocene Holocene (blue clays, sands and gravel) and swamp deposits from the Lower Holocene Upper Holocene (especially in the Ecedea Plain, where large areas covered with black peat occur) [3]. The Ecedea swamp is considered to have been "... one of the largest eutrophic swamps on the continent" [18], but a recent complex, ecological study brings evidence of a shift toward mesic habitats due to water table lowering [2].

The dominant soils are preluvisols (luvisols) and stagnosols, and in some microdepressions (with water table outcrops), acidic gleysols (in the west) or limnosols, often with a high degree of salinity, have formed. In particular site conditions, gleyic chernozems or fluvisols also occur. In areas that were subject to drainage works, the solonetz soils have expanded continuously [3].

The regional climate is of temperate-moderate type, but with less hot summers but longer and harsher winters than in the rest of the Pannonian Plain, with an annual mean temperature of $9.5^{\circ} \mathrm{C}$ and a mean rainfall between 600 and $800 \mathrm{~mm}$ per year. 
The first research on the flora of the Ecedea wetlands was carried out at the end of the 18th century by Piller, Kitaibel, and in the 19th century by Pokorny [2].

The beginning of the 20th century is poor in extensive botanical research, except for some sporadic floristic reports [10, 16, 20,32]. Later on, similar observations on the vegetation of the north-western Romania [5] and, in particular, of the Ecedea swamps and Ierului valley were made [29, 30]. The first phytosociological (geobotanical) study in this large region was carried out in the perimeter of the villages Boghiș and Vetiss [7], followed by similar studies on the flora and vegetation of Satu Mare county [4, 26], of the Someș Plain [19] and of some localities [8, 17]. Finally, in 1995 the consistent synthesis "Flora and Vegetation of Satu Mare County" was published [22].

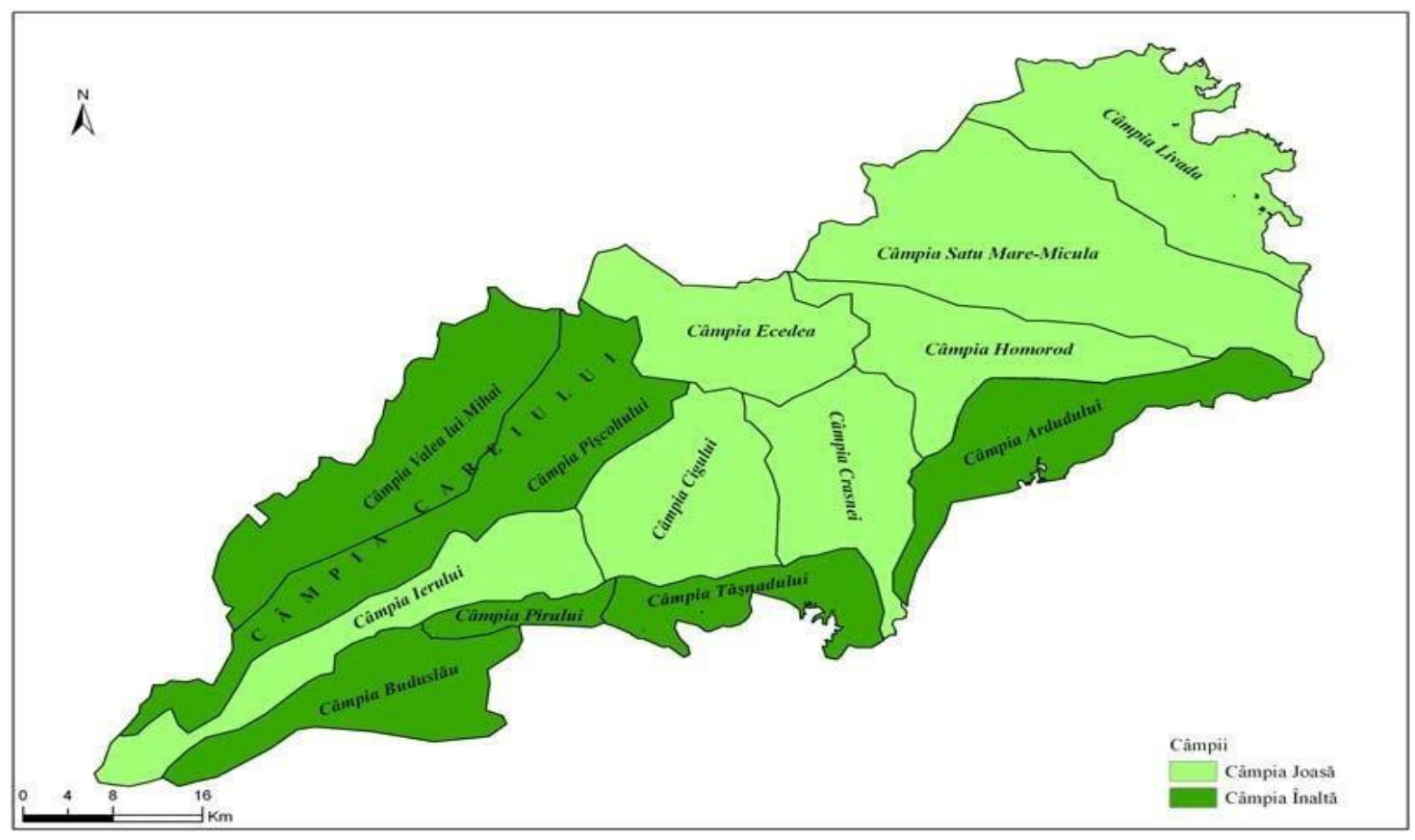

Fig. 1: Subdivisions of the Someș Plain (after Posea [28])

The post-glacial evolution of the vegetation of the northern plain sector was revealed by the spore-pollen analyses of the peat from Berveni [27], Coasta Boinești [9] and Vărgat Lake or Dungat Lake (Csikos) [24].

The main objective of this preliminary account was to classify and characterise the extant aquatic and marshy plant communities, and to compare them with the old vegetation data, in order to detect obvious changes in species composition that are very likely due, to a large extent, to the drainage and desiccation works performed in the area.

\section{Materials and Methods}

The vegetation inventory was carried throughout most of the study area in the summer of 2017. The floristic survey was based on the methodology designed by BraunBlanquet (1964) but taking into account also the particularities of the Romanian vegetation [6, 12]. 
The coenotaxonomic classification and nomenclature of the plant associations followed the published monographs by Coldea et al. [11], Doniţă et al. [15], Ivan [21], Sanda et al. [31].

Some plant associations previously reported in the area were refound so fragmented, reduced or degenerated, that it was no longer possible to carry out proper phytosociological investigations.

\section{Results and Discussions}

So far, in the three subdivisions of the lower Someș Plain, 59 plant associations have been distinguished, of which only 20 were represented by aquatic and marshy cenoses. This low number can be explained by the dramatic environmental changes caused by various anthropogenic activities, of which the land reclamation by drainage and desiccation stands out as the most important. Moreover, the real number of aquatic and marshy plant associations may be even lower due to redundant nomenclatural synonyms. By reference, Gomoiu [19] reported a number of 60 aquatic and marshy plant associations described in northern Someș Plain in the last 120 years.

The currently acknowledged aquatic and marshy plant associations are framed in the following coenotaxonomic system:

Cl. LEMNETEA (R. Tüxen 1952) de Bolós et Masclans1955

Ord. LEMNETALIA MINORIS (R. Tüxen 1955) de Bolós et Masclans 1955

Al. Lemnion minoris (R. Tüxen 1955) de Bolós et Masclans 1955

1. Lemnetum minoris Oberdorfer ex Th. Müller et Görs1960

Al. Lemno-Salvinion natantis Slavnić1956

2. Spirodelo - Salvinietum Slavnić 1956

Ord. HYDROCHARIETALIA Rübel1933

Al. Hydrocharition Rübel 1933

3. Hydrochari - Stratiotetum (Langendoch 1935) Westhoff1942

Al. Ceratophyllion demersi (Soó 1927) Den Hartog et Segal 1964

4. Ceratophylletum demersi (Soó 1927) Hild1956

Cl. POTAMOGETONETEA PECTINATI Klika in Klika et Novák 1941

Ord. POTAMOGETONETALIA PECTINATI W. Koch 1926

Al. Nymphaeion albae Oberdorfer 1957

5. Myriophyllo verticillati - Nupharetum luteae Koch1926

6. Potametum natantis Soó1927

7. Trapetum natantis Kárpáti1963

Cl. ISOËTO - NANOJUNCETEA Br.-B1. et R. Tüxen ex Westhoff et al. 1946

Ord. NANOCYPERETALIA Klika 1935

Al. Nanocyperion Koch ex Libbert 1932

8. Juncetum bufonii Felföldy 1942

9. Eleochariteto acicularis - Limoselletum aquaticae Wendelberger-Zelinka 1952

A1. Verbenion supinae Slavnić1951

10. Pulicario - Menthetum pulegii Slavnić1951

Cl. PHRAGMITETEA AUSTRALIS R. Tüxen et Preising 1942

Ord. PHRAGMITETALIA Koch 1926

Al. Phragmition communis Koch 1926 
11. Scirpo - Phragmitetum Koch 1926

12. Typhaetum angustifoliae Pignatti1953

13. Typhaetum latifoliae Lang 1973

14. Glycerietum maximae Hueck1931

15. Typhaetum laxmannii (Ubrizsy 1961) Nedelcu1968

Ord. BOLBOSCHOENETALIA MARITIMI Hejny in Holub et al. 1967

Al. Cirsio brachycephali - Bolboschoenion (Passarge 1978) Mucina 1993

16. Bolboschoenetum maritimi Eggler1933

Ord. NASTURTIO - GLYCERIETALIA Pignatti 1953

Al. Phalaridion arundinaceae Kopecky 1961

17. Phalaridetum arundinaceae (Koch 1926) Libbert1931

Ord. OENANTHETALIA AQUATICAE Hejny in Kopecky 1961 ex Hejny 1965

Al. Oenanthion aquaticae Hejny ex Neuhäusl 1959

18. Oenantheto - Rorippetum Lohmeyer 1950

Ord. MAGNOCARICETALIA Pignatti 1953

Al. Magnocaricion elatae Koch 1926

19. Caricetum acutiformis Eggler1933

20. Caricetum ripariae Knapp et Stoffer 1962

The aquatic vegetation is quite largely distributed in both still waters (lakes, ponds, meanders) and flowing streams, i.e. in the Homorod Canal (at Păulian) and the numerous drainage canals from localities like Boghiș, Doba, Moftinu Mic, Pelișor, Noroieni and Bercu Nou. A relatively high number of species was observed in Myriophyllo verticillati-Nupharetum luteae communities, in which species from the classes Lemnetea and Phragmitetea occur, in addition to those from Potamogetonetea. The phytocoenoses of Spirodelo-Salvinietum (in the localities Boghiș, Pelișor and Doba) and Hydrochari-Stratiotetum (from Nisipeni) are undoubtedly remnants of the natural aquatic vegetation. Actually, the Hydrochari - Stratiotetum was reported at Doba [19] and surveyed at Nisipeni, after being considered disappeared from the area.

The vegetation of muddy sites along the shores of lakes and stagnant waters is generally dominated by annual, small-sized species. Three such plant associations were distinguished, of which the richest in species was Pulicario-Menthetum pulegii, mainly because of the infiltration of Molinio-Arrhenatheretea species. Remarkable for its re-establishment after decades of absence, the phytocoenoses of Eleochariteto acicularis-Limoselletum aquaticae were found in small patches only in two localities: Rătești (within the Cerhat Forest) and Adrian. The small number of associations ascribed to Nanocyperetalia is very likely due to the extended drainage of the wetlands [2].

The marshy vegetation includes phytocenoses installed on undeveloped, hydromorphic soils featuring a clay-rich horizon and located both along streams and at the edge of stagnant waters or in micro-depressions. The 10 associations included in the class Phragmitetea are characterised by phytocenoses relatively rich in species, except for those assigned to Bolboschoenetum maritimi that are usually installed on hyposalic soils. The most common community types were those dominated by reed (Scirpo-Phragmitetum), cattails ( Thyphetum latifoliae, Typhaetum angustifoliae) and great mannagrass (Glycerietum maximae). 
Of the tall sedge communities, the most common appeared to be Caricetum acutiformis, which persists even in habitats in course of drying. That may explain the occurrence of scattered bare spots but also the establishment of weeds and species typical of meso-hygrophilous grasslands, all representing effects of habitat euthrophication and human activities. Caricetum ripariae was found sporadically and featuring a rather low floristic diversity.

Intensive agricultural practices have affected even the few remnants of natural habitats, in which various secondary processes are noticable, such as: soluble salt accumulation (salinization), water and soil enrichment in organic matter (eutrophication), soil compaction, etc. Lately, the expansion of drier and/or weed-dominated facies (ruderalization) of the marshy communities has been observed throughout the area. Once frequently observed in the landscape, the characteristic formation of island-like patches of sedge vegetation (popândaci) embbeded within the grassland matrix, are nowadays in regress throughout the whole Someș River Plain.

The most conspicuous, newly formed habitats in the study area are the anthropogenic lakes, such as those from Moftin, Adrian and Bercu, which contain moderately eutrophicated waters and are already surrounded by outlined strips of shore vegetation.

By reference to different European, national or regional lists of endangered or rare plant species $[1,13,14,25]$, a series of taxa recorded in releves are worth to be protected, such as: Marsilea quadrifolia included in the Annex II of Habitats Directive 92/43/EEC; Salvinia natans and Trapa natans included in the Annex 3 of GEO 57/2007; Euphorbia palustris, Limosella aquatica, Nuphar lutea, Nymphaea alba, Rumex hydrolapathum, Sagittaria sigittifolia, Stratiotes aloides, Utricularia vulgaris, included in the red list of plants of the Satu Mare county. Among the numerous adventitious species recorded, some feature growing populations, like Ambrosia artemisiifolia, Amorpha fruticosa, Bidens frondosa, Echinocystis lobata, Erigeron annuus, Reynoutria japonica, Veronica peregrina, Xanthium italicum.

In conclusion, a generalised replacement of marshy vegetation by drier facies was observed, as we move away from the time of drainage work suspension. The main spatial distribution feature of the aquatic and marshy vegetation in the study area is its insularization, owing to the fragmentation of their habitat by agricultural areas and the interruption of the vast network of surface waters. On the other hand, two plant associations, which disappeared 70-80 years ago owing to wetland drainage, have reappeared in the lower Someș Plain in recent years.

\section{REFERENCES}

1. Ardelean, G., (coord), 2014, Arii și specii protejate în județul Satu Mare, Ed. "Vasile Goldiș" University Press, Arad.

2. Ardelean, G., Karácsonyi, K., 2003, Flora şi fauna Ecedei, de la mlaştină la câmpie, Ed. Daya, Satu Mare.

3. Asvadurov, H., Boeriu, I.,1983, Solurile județului Satu Mare, Centrul de Material Didactic și de Propagandă Agricolă, București.

4. Asvadurov, H., Dragu, I., 1967, Cercetări geobotanice pe Câmpia Someșului, Dări de seamă , Comit. Geol., 1965-1966, București, 53 (2): 331-326.

5. Borza, A.,1929, Vegetația și flora Ardealului. Schiță geobotanică, Rev. Transilvania, Banatul, Crișana, Maramureșul, I: $251-270$. 
6. Borza, A., Boșcaiu, N., 1965, Introducere în studiul covorului vegetal, Ed. Acad., București.

7. Buia, A., 1940, Materiale pentru studiul fânețelor și pășunilor din regiunea Satu Mare-Sălaj, Bul. Acad. Agron, Cluj, VIII (1939): 347-361.

8. Burescu, P., 2003, Flora și vegetația zonelor umede din nord-vestul României, Ed. Acad., București.

9. Cârciumaru, M., 1970, Analiza palinologică a stratelor de vârstă gravețiană de la coasta Boinești, Rev. Muzeelor, VII (4): 353-354.

10. Ciurdariu, E.,1914, A lapok anthropogeográphiája, különös tekintettell az Ecsedi- lápra, Budapest.

11. Coldea, G., Sanda, V., Popescu, A., Ștefan, M., 1997, Les Associations végétales de Roumaine, Les associations herbacées naturelles, Presses Universitaries, Cluj.

12. Cristea, V., Gafta, D., Pedrotti, F., 2004, Fitosociologie, Ed. Presa Univ. Clujeană, Cluj-Napoca.

13. Dihoru, Gh., Negrean, G., 2009, Cartea roșie a plantelor vasculare din România, Ed. Acad. Române, București.

14. xxx, Directiva habitate $92 / 43 /$ C.E.E.

15. Doniţă, N., Popescu, A., Paucă-Comănescu, M., Mihăilescu, S., Biriş, I.-A., 2005, Habitatele din România, Ed. Tehnică-Silvică, Bucureşti.

16. Fodor, F., 1910, Adatok Szatmár vármegye flórájának ismeretéhez, Egyet. Term. Tud. Szov. Evk., 1909, V: $35-52$.

17. Gergely, I., Rațiu, O., Moldovan, I., 1977, Vegetația helohidatofită și higrofită din împrejurimile comunei Livada, Contrib. Bot., Cluj-Napoca: 19-30.

18. Gligor, V., Bilașco, S., Filip, S., David, N., 2010, Potențialul morfologic al microregiunii Tăşnad, Geogr. Napocensis, 4 (2): 28-47.

19. Gomoiu, M.T., (coord), 2009, Zonele umede. Abordare ecologică, Casa Cărții de Știință, Cluj-Napoca.

20. Gull, V., Liffa, A., Timko, I., 1905, Az Ecsedi-láp agrogeológiai viszonyai, A Magy. Kir. Foldt. Int. Evk., XIV, 1902-1905: 252-299.

21. Ivan, D., (coord), 1992, Vegetația României, Ed. Tehnică agricolă, București.

22. Karácsonyi, C., 1995, Flora și vegetația județului Satu Mare, Ed. Muzeului Sătmărean, Satu Mare.

23. Lerch, G., 1980, Pflanzenökologie, I-II, Akademie Verl., Berlin.

24. Lupșa, V., Karácsonyi, C., Boșcaiu, M., 1986, Analiza polinică a sedimentelor din Lacul Vărgat (jud. Bihor), Ocrot. nat. med. inconj., 30 (2): 130-132.

25. xxx, OUG 57/2007, Privind regimul ariilor naturale protejate, conservarea habitatelor naturale, a florei și faunei sălbatice. Monitorul oficial nr.442 din 29 iunie 2007, partea a-III-a, ANEXA nr. 3 SPECII de plante si de animale a căror conservare necesită desemnarea ariilor speciale de conservare și a ariilor de protecție specială avifaunistică.

26. Negrean, G., 1981-1982, Contribuții micologice I. Județul Satu Mare, St. Com., V-VI : 435-439.

27. Pop, E., 1957, Analize de polen în regiuni de câmpie, Bul. Şt., Secţia biol., şt. agric. (Seria bot.), IX (1): 5-32.

28. Posea, Gr., 1997, Câmpia de Vest a României, Ed. Fundației "România de mâine", București.

29. Prodan, I., 1956, Aspecte din vegetația zonei de vest a RPR., Bul. Științ., Seria biol. șt. agric., VIII (1): 5-45.

30. Prodan, I., 1957, Contribuții la flora R.P.R., Bul. Științ. Sect. biol. Șt. agric. Seria bot., IX (4): 285-326.

31. Sanda, V., Ollerer, K., Burescu, P., 2008, Fitocenozele din România. Sintaxonomie, structură, dinamică şi evoluţie, Ed. Ars Docendi, București.

32. Timko, I., 1904, Az Ecsedi-láp, Földr. Közl., XXXII: 369-381.

\section{VEGETAȚIA ACVATICĂ ȘI PALUSTRĂ DIN CENTRUL CÂMPIEI JOASE A SOMEȘULUI: CARACTERIZARE GENERALĂ}

\section{(Rezumat)}

În vederea unui studiu mai amplu privind vegetația din Câmpia Joasă a Someșului, lucrarea de față sintetizează observațiile floristice efectuate asupra vegetaţiei acvatice și palustre, care era dominantă în urmă cu cca. trei secole, când au început lucrările de asanare. Prin metoda fitosociologică au fost identificate 20 de asociații vegetale 
încadrate în patru clase de vegetație. Fără a prezenta tabele fitosociologice în această primă etapă, clasificarea cenotaxonomică, distribuția şi compoziția speciilor din comunitățile de plante identificate sunt expuse succint, făcându-se referire atât la procesul de uscare a zonelor umede și schimbările successionale, cât și la noile lacuri de acumulare de origine antropică. Valoarea conservativă a unor comunități de plante este evidențiată prin prezența unor specii amenințate, care sunt incluse în Directiva Habitate la nivel european, dar figurează și în cartea roșie/ listele roșii regionale sau naționale.

Received: 22.10.2021; Accepted: 26.10.2021. 